This item was submitted to Loughborough's Research Repository by the author.

Items in Figshare are protected by copyright, with all rights reserved, unless otherwise indicated.

\title{
The lady footballers: struggling to play in Victorian Britain [book review]
}

PLEASE CITE THE PUBLISHED VERSION

http://dx.doi.org/10.1080/13573322.2013.721576

PUBLISHER

(C) Taylor \& Francis (Routledge)

VERSION

SMUR (Submitted Manuscript Under Review)

LICENCE

CC BY-NC-ND 4.0

REPOSITORY RECORD

Hill, Joanne L.. 2019. "The Lady Footballers: Struggling to Play in Victorian Britain [book Review]". figshare. https://hdl.handle.net/2134/12212. 
This item was submitted to Loughborough's Institutional Repository (https://dspace.lboro.ac.uk/) by the author and is made available under the following Creative Commons Licence conditions.

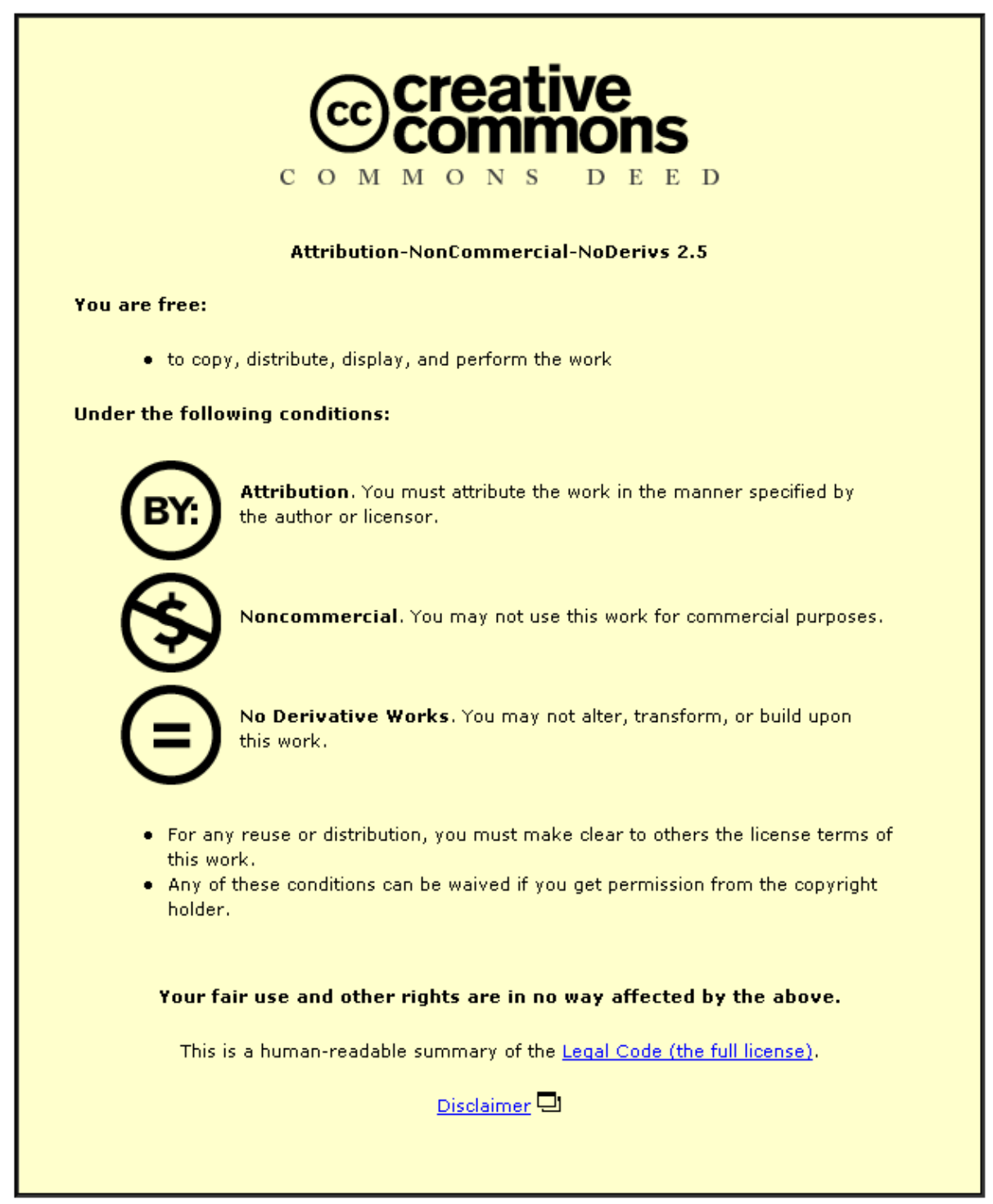

For the full text of this licence, please go to: http://creativecommons.org/licenses/by-nc-nd/2.5/ 
Notice: This is the author's version of a book review published in Sport, Education and Society, 2013 (18:3, 273-276). The review appears here in its pre-publication format in lieu of the publisher's version of record. The published review can be found at http://www.tandfonline.com/doi/abs/10.1080/13573322.2013.721576

\section{The Lady Footballers: Struggling to Play in Victorian Britain}

James F. Lee, 2008

Abingdon, Oxon, Routledge

$£ 24.95$ (pbk), 132 pp + xix

ISBN: 978-0415603133

James F. Lee's engaging account of the British Ladies' Football Club (BLFC) in 1895-1896 delves into the founding of one of the first professional women's football clubs in the UK. It follows the build-up and response to the BLFC's first match at Alexandra Park, Crouch End in London on 23 March 1895 and explores the social factors behind their gradual demise. Drawing crowds as high as ten thousand strong during a series of matches on their London, English and Scottish tours, Lee nevertheless offers the aim of the book as 'answering the question why the change [the introduction of women's football] ... was so widely discredited' (xviii). Lee frames his history of the BLFC among aspects of social upheaval at the time, considering that femininity and masculinity were being redefined and pressure was growing for women's greater involvement in public life. In this sense, the book considers the social world around football as offering an insight into contemporary social practices and gender boundaries. Among a 'crisis of masculine identity' (4) at the end of the century came the BLFC's bold attempt to play football, in knickerbockers, and to get paid for it.

The Introduction begins by commenting on the slow pace of change in women's sports, but, from the author's US perspective, football's shattering of 'the time-honoured myths regarding women as athletes' (xv). Here Lee also outlines the methodology, specifically newspaper reports, editorials and correspondence of 'the week before, week of and week after the local match' (xvii); plus sports magazine commentary and biography and public records on the founders and players. These primary sources offer a particular view of public opinion on the club, but also suggest the ways in which opinion was shaped, Lee commenting on the more or less favourable response to the BLFC from liberal and conservative newspapers respectively.

The first chapter 'Crouch End Rubs its Eyes and Pinches its Arms' takes us into the social world surrounding men's football at the time. This was a space were women were few even as spectators. The most interesting aspects of the book come in reflections on the social implications of women's football and the relationship to political and social shifts. Lee creates images of end of century uncertainties in both men's and women's roles in this opening chapter. He highlights Oscar Wilde's trials concerning "indecent" acts and the 
murder in Ireland of Bridget Cleary by her husband who believed she had been replaced by a fairy changeling. Both occurred in the same month that the BLFC's first match in Crouch End was scheduled: evidence that '[t]his was a new world, typified by the 'new woman' and effeminate men, yet still the old world of 'ignorance' and 'superstition' (5). Indeed, the founder Miss Nettie Honeyball and patron Lady Florence Dixie themselves made a connection to the new woman, framing women's football as part of the campaigns for rational dress and women's good health. The BLFC suggested radical statements about corsets, bustles and skirts as a metaphor for women's restricted place in society. In 'The Threat of Robust Mothers' football is compared to tennis, golf and cricket, sports also increasing in women's involvement at the time, yet sports that compromised rigorous play for proper dress. Other appropriate activities for women included skating, croquet, archery and angling, which Lee calls sports 'that men and women can play together' (10), although the basis for this point is not so much explained and may benefit from some further analysis of the social construction of the body and gender in contextual perspective.

In 'The Upholsterer's Daughter and the Aristocrat' Lee pieces together information about the founders of the club. It emerges that Nettie Honeyball and Florence Dixie 'were women of action, both shared the same passion, and neither was afraid to say what she felt' (33). Little is known about the other players on the teams or how they were recruited, beyond their probable middle-class backgrounds, as Honeyball claimed she turned down a number of working-class women who applied to join the club. The following chapters, 'As Natural a Game for Girls as for Boys' and 'This Club Does Not Play in Fashion's Dress' juxtapose Honeyball's and Dixie's own promotional letters and features in Sketch and the Pall Mall Gazette with less favourable coverage. Notable are the mocking suggestions of rule modifications for the lady footballers in Punch: 'The goals shall consist of two large marquees, in this the respective captains, assisted by other lady-members, shall reside over afternoon tea' (Punch, 1895, cited on p. 43). Enriching the story is the reproduction in full of some of the more amusing pieces that indicate the tone of opinion: humouring but rarely supporting the BLFC. Also reproduced are team photographs of the BLFC's two sides, the Reds and the Blues, in their knickerbockers, blouses, caps, boots and shin pads. Strikingly, some of the players sit with legs apart, arms folded, as they recline in their seats, displaying a confident and wonderfully unladylike air. Lee again compares the dress of the lady footballers to that of the All-English Women's Hockey Association that retained long skirts in the interests of fashion and decorum. The point is firmly made: for the lady footballers to wear knickerbockers was truly 'revolutionary' (71).

Turning to reports of the matches themselves in the sixth and seventh chapters 'Grown Men Weep' and 'Stop the Game, You've Lost Your Ribbons, Miss!', Lee is reliant on often disparaging accounts of the games that simultaneously mocked the level of skill and wrote far more about the appearance of the players than their abilities or the action. It appears that much of the play was deemed low quality and embarrassing to watch, although readers may remain unconvinced that this is not bias on the part of the reporters. We continue to hear the same enduring assumptions concerning women playing "men's sports" today: where a woman was seen as a bad player this was indication that all women are bad players; those 
skilled players were suspected of being boys. This 'double standard' (68) is explored in chapter 9, 'Tommy' and Mrs Graham: Gender Confusion on the Pitch'. Lee finds extensive speculation on 'Tommy', one of the BLFC players, in the Glasgow Evening Times among other newspapers. We learn that Tommy's skill endeared her to the crowds but that she could not possibly be a woman (or girl) because of her short hair and also her ability to run as though she had never been trapped up in a corset and skirts. At the same time another player noted for her considerable talent, goalkeeper Mrs Graham, was never regarded as a boy, presumably given her more feminine looks and because she played in a skirt rather than knickerbockers. As with the clothing controversy, Lee wonders whether the BLFC benefitted from and indeed courted the attention on gender confusion.

In 'Barnstorming through Britain: 1895 and 1896', the eighth chapter, Lee follows the trail through a series of matches around England, often two or more a week, during April and May 1895, and then on to a related ladies' team's tour of Scotland in 1896, run by Mrs Graham and playing against various teams including some men's teams. No further matches after the West Calder match on 3 July 1896 are reported. Lee speculates on the decline of the British Ladies' Football Club. While the BLFC and Mrs Graham's successors appear not to have been stopped from playing, and indeed seem to have been humoured as they gathered large crowds at most matches across the UK, Lee wonders whether declining attendance and increasingly poor receptions discouraged the lady footballers. Violence amongst spectators, sometimes towards the players as they entered or exited the pitch, was reported at some matches. This happened as they began to play male opponents, Lee suggests; indicating that women's football may have become acceptable as long as it remained separate from the men's game. That the founders of the BLFC wished for the women's game to not be separate, different and hence inferior to the men's game is suggested as reason for their failure. Lee offers hints of tension in contemporary society between an older version of femininity restricted and confined - and the 'New Woman' - physically active, healthy and entering male arenas. 'More troubling', he considers, 'was how to deal with those women who didn't conform to any standard [of femininity], whose play was good in and of itself' (102). Further literature for analysis on the gender relations or ideology of the time would strengthen these suppositions.

This book outlines the last significant women's involvement in spectator football on a national level before the upsurge in popularity during and after the First World War. Indeed thoughts of the reasons for the success of teams such as the Dick, Kerr Ladies, particularly how they drew crowds greater than those at men's matches, are never far away. Neither can readers forget the 1921 FA decision to ban women's matches on FA affiliated club pitches. This later period is examined in the final chapter of the book, 'Life After Death', consulting sources including Williamson (1991) and Newsham (1994). Lee attempts comparisons between the BLFC and the later more successful Dick, Kerr Ladies and their contemporaries. The argument that women's football grows at times of social change is convincing, but analysis of the "barriers" faced by the BLFC can be confusing, as they were in fact welcomed for a number of their matches. It is heartening that in Victorian England women were not banned from playing football, although they did receive largely discouraging and mocking 
press, and some violence from spectators. Despite some doctors' concerns that playing football was bad for reproductive health, and the deep controversy around the BLFC players not wearing floor length skirts, the club was still able to draw paying spectators. Indeed, some newspaper coverage seems almost positive, wishing the women to play well in order for the support to be justified. Lee wonders whether the radical Dixie was a bad choice of patron for the club, too keen for the women to play sports like men, where more feminine practices and appearances would have ensured longer term, if less exciting, success. Football in the late Victorian period challenged many ideas about women's physical capability, dress, and social roles. Their eventual "failure" is presented by Lee as testimony to the club being ahead of its time. The short life of the BLFC indicates that they indeed tried to reach too high too soon although Honeyball and Dixie would no doubt have argued that there is no point in half measures. Ultimately, the declining coverage means that the trail runs dry without revealing the full extent of the BLFC's history and we are unable to entirely celebrate the achievements of the lady footballers. The BLFC, middle class ladies, had tried to play a man's game in a working class way (for money) and hence drew the ire of the press and public. The BLFC were seen as a spectacle of 'knickerbocker-clad harridans ... under the leering gaze of the playing public' (xvi) and not a legitimate sporting endeavour.

This is a rich account of extensive primary research into the British Ladies' Football Club, offering an addition to broader works on Victorian women's sports participation. The Lady Footballers will also interest readers from outside of football studies, for its consideration of contemporary class and gender relations among long term developments in women's rights, clothing and public engagement.

\section{References}

Newsham, G. (1994) A league of their own! The Dick, Kerr Ladies Football Team. (Chorley: Pride of Place).

Punch (1895) A revised code. 2 Feb. 1895, 49.

Williamson, D. (1991) Belles of the ball: The early history of women's football. (Devon: R\&D Associates).

Joanne Hill, Loughborough University 